\title{
DETECTING FINANCIAL STATEMENTS FRAUD IN SELECTED PHARMACEUTICAL COMPANIES IN INDIA
}

\section{Dr. Chetana R. Marvadi}

Assistant Professor S.D. School of Commerce,Gujarat University, Ahmedabad-380009 Gujarat, India

ABSTRACT financial performance. Major corporate financial statement Frauds get away in the name of creative accounting. But, they need to be studied for lessons learned and strategies to avoid or reduce the incidence of such frauds in the future. It is essential for shareholders, particularly the common man who does not have any access to the company except reported financial numbers. This research paper attempts to detect the practices of financial statement fraud in the Pharmaceutical Sector in India for investors' interest using Earnings quality, De Angelo and Beneish models of fraud detection. The result confirms the presence of financial statement fraud in the companies under study. It is therefore expected that the study will help to improves investor's belief of a company's performance, as reflected in their financial numbers.

\section{KEYWORDS : "Financial Statement Fraud", "Earnings Quality", "De-Angelo Model"," Beneish Model"}

\section{INTRODUCTION:}

In the business environment, firms are expected to disclose accurate and reliable financial information. Financial market participants can only make rational and accurate investment decisions when firms report accurate and reliable accounting information. Money and capital markets' efficiency heavily depends on the quality of accounting information reported by firms. Accounting manipulation is one of the most discussed topics in today's business environment. According to a study conducted by the Association of Certified Fraud Examiners (ACFE), fraudulent financial statements accounts for approximately $10 \%$ of incidents concerning white collar crime. Fraud is a major concern for organizations world-wide. Governments and regulators are now focusing on management's responsibility for effective fraud management programs. It is not a matter whether your organization is large or small or what country or industry your organization is in, as long as humans are involved in organizations, the risk of fraud is real.

Financial statement frauds are actions which are taken to intentionally distort a company's reported financial performance. This manipulation is carried out with the help of accrual accounting. This is where Earnings management creeps in. Major corporate financial shenanigans get away in the name of creative accounting. But, they need to be studied for lessons learned and strategies to avoid or reduce the incidence of such frauds in the future. It is essential for shareholders, particularly the common man who does not have any access to the company except reported financial numbers. This research paper attempts to detect the financial statement fraud in the Pharmaceutical Sector in India for investors' interest. Pharmaceutical Sector is one of the most upcoming sectors in India. It is more volatile for these aggressive accounting manipulations because of the keen competition and therefore it becomes imperative to make financial users aware about them by the Indian corporate.

Thus, the present study tries to unleash the dimension of financial Statement fraud in Indian pharmaceutical sector for shareholders in particular and society at large.

\section{Literature review:}

Financial statements fraud has always been an area of interest to the researchers worldwide.

- Feng Li et al (2011) analysed the link between earnings management and earnings quality for the Chinese firms listed in the Shanghai and Shenzhen stock exchange for the period of 2003-2007. The earnings quality is measured by four separate earnings attributes: accruals quality, earnings persistence, earnings predictability, and earnings smoothness. We find that the stressed/bankrupt firms prefer opportunistic earnings management; the nonstressed/non-bankrupt firms are more likely to choose more efficient earnings management than the stressed/non-bankrupt firms. We find that earnings management performs better than earnings quality in predicting future profitability. We also find that the earnings quality has deteriorated over the sample period; the number of stressed/bankrupt firms increased and the number of non-stressed/non-bankrupt firms decreased. Beneish, M.D. (2001) havs made comparision of three definitions of earnings management used by accounting researchers and three methods of estimating it: aggregate accruals, specific accruals and discontinuities in earnings distribution. He has discussed evidence relating to the reasons for income-increasing earnings management, income-decreasing earnings management and specific contexts, e.g. financial institutions with regulatory constraints. This study concluded that, although the evidence is limited, managers are more likely to manipulate income up rather than down; and identifies some opportunities for further research. Bistrova, J. \& Lace, N. (2012) have analysed 118 companies quoted on Central and Eastern European stock exchanges. Their findings prove the negative relationship between the quality corporate governance and the level of accruals. The statistically significant results are based on the cash flow accruals, while balance sheet accruals, though showing a consistent pattern, do not provide significant evidence. Net income and operating cash flow discrepancy also detect lower than average earnings quality if a company has weak corporate governance system, while sufficiently good earnings plausibility in case of the well-managed companies. SandeepGoel (2013) has attempted to detect financial shenanigans in the Telecom Sector of India using Beneish Model. He has tried to contribute by detecting these shenanigans in totality not in isolation, on five parameters: quality of earnings, quality of revenue, volatility of income, discretionary accruals, and manipulation score. The results indicate the visibility of financial shenanigans in the companies under study. Normah Omar et.al.(2014) discusses a local case of MMHB and analyses how the fraud was committed and the detection techniques involved. Beneish Model and Ratios Analysis were selected as detection tools in reference to this case. The 
operating efficiency ratio analysis shows that the company recorded fictitious revenue amounting to RM 198,727 . Therefore, these tools used in our investigation confirm that the company involve in manipulating their financial statements.

Research methodology:

The study specifically aims at the following objectives:

- To test quality of earnings for indicative earnings manipulation for selected companies.

- To detect the magnitude of discretionary accruals in regard to potential financial statement fraud.

- To find out the manipulation score for the units under study as a part of final verification of detected financial statement fraud.

- To highlight the major areas of concern in accounting manipulations in these undertakings for their future viability

Sample Size and Data Collection:

The present study covers the companies in the pharmaceutical sector of India. This study is based on the secondary data of 11 years from 2006 to 2016. The companies chosen as per the data availability are given below.

- Cipla Ltd

- Lupin Ltd

- Sun Pharmaceutical Industries Ltd

- Cadila Healthcare Ltd

- Divi's laboratories Ltd

- Dr.Reddy's laboratories Ltd

- Torrent Pharmaceuticals Ltd

- AurobindoPharma Ltd

- Biocon Ltd

- Piramal Enterprises Ltd

Tools/Techniques:

The following tools and techniques are used to identify fraudulent financial statements:

\section{- Quality of Earnings model:}

Quality of earnings is computed as the percentage of operating cash flow to net income of a firm. Higher the quality of earnings, lower the chances of earnings manipulation.

\section{- The De Angelo Model:}

The De Angelo Model is considered here for computing discretionary accruals. It is computed as follows:

$$
D A C_{i t}=\frac{T A_{i t}-T A_{i t-1}}{A_{i t-1}}
$$

Where:

DACit is discretionary accruals for firm $\mathrm{i}$ in period $\mathrm{t}$;

TAit and Ait -l are Total Accruals and Total Assets for period t and t-l for firm I.

The above model has been used to determine the potential financial statement fraud of the units under study.

\section{- The Beneish M-Score Model:}

The Beneish M-Score Model (Beneish Model), deployed as a financial forensic tool, can assist in evaluating the probability of earnings manipulation in a company, as well as identifying areas that may require greater scrutiny. Beneish M-Score is a method that can be used to detect companies with a tendency to commit fraud on their financial statements (Beneish, 2012).

Table :1 Quality of Earnings of Sample Companies (\%)
Empirically, companies with higher M-Score, have higher tendency to commit fraud.

If the M-score > -2.22 , it shows indications of financial fraud within companies.

The $\mathrm{M}$ score is based on a combination of the following eight different indices:

1. DSRI = Days' Sales in Receivables Index. This measures the ratio of days' sales in receivables versus prior year as an indicator of revenue inflation.

2. GMI $=$ Gross Margin Index. This is measured as the ratio of gross margin versus prior year. A firm with poorer prospects is more likely to manipulate earnings.

3. $\mathrm{AQI}=$ Asset Quality Index. Asset quality is measured as the ratio of non-current assets other than plant, property and equipment to total assets. AQI is the ratio of asset quality versus prior year.

4. SGI $=$ Sales Growth Index. This measures the ratio of sales versus prior year. While sales growth is not itself a measure of manipulation growth companies are likely to find them-selves under pressure to manipulate in order to keep up appearances.

5. DEPI $=$ Depreciation Index. This is measured as the ratio of the rate of depreciation versus prior year. A slower rate of depreciation (DEPI greater than 1) may means that the firm is revising useful asset life assumptions upwards, or adopting a new method that is income friendly.

6. SGAI = Sales, General and Administrative expenses Index. This measures the ratio of SGA expenses to the prior year. This is used on the assumption that analysts would interpret a disproportionate increase in sales as a negative signal about firms future prospects

7. LVGI = Leverage Index. This measures the ratio of total debt to total assets versus prior year. It is intended to capture debt covenants incentives for earnings manipulation.

8. TATA - Total Accruals to Total Assets. This assesses the extent to which managers make discretionary accounting choices to alter earnings. Total accruals are calculated as the change in working capital accounts other than cash less depreciation.

These eight variables are then calculated together using the following formula:

$\mathrm{M}=-4.84+0.92^{*} \mathrm{DSRI}+0.528^{*} \mathrm{GMI}+0.404^{*} \mathrm{AQI}+$ $0.892{ }^{*} \mathrm{SGI}+0.115^{\star} \mathrm{DEPI}-0.172{ }^{*} \mathrm{SGAI}+4.679$ * $\mathrm{T}$ A T A $.327{ }^{*} \mathrm{LVGI}$

A score greater than -2.22 (i.e. less negative than this) signals a strong likelihood of a firm being a manipulator. An M-Score of less than -2.22 suggests the company will not be a manipulator. The analysis of the financial statement require at least two period of financial reporting to detect unusual event. However, to identify the trend of the company's financial statement reporting, it is suggested to analyse the data for five reporting period.

\section{DATA ANALYSIS AND DISCUSSION:}

The followings are the results of various analytical tools applied:

\section{- Earnings Quality:}

Following is the testing of quality of earnings of the sample companies under study.

\begin{tabular}{|c|c|c|c|c|c|c|c|c|c|c|c|c|}
\hline Company name & 2006 & 2007 & 2008 & 2009 & 2010 & 2011 & 2012 & 2013 & 2014 & 2015 & 2016 & Average \\
\hline Cipla Ltd & 45.5855 & 50.0629 & 54.1595 & 48.0399 & 96.3626 & 102.864 & 146.36 & 91.662 & 130.488 & 89.027 & 123.65 & 88.93 \\
\hline Lupin Ltd & 62.2099 & 53.3735 & 58.6404 & 99.2445 & 82.0689 & 56.665 & 59.404 & 79.992 & 65.748 & 118.945 & 32.93 & 69.93 \\
\hline Sun Pharma Ltd & 67.3828 & 71.6391 & 61.7461 & 99.7787 & 73.2343 & 88.404 & 78.891 & 20.614 & 85.028 & -10.08 & 115.93 & 68.42 \\
\hline
\end{tabular}




\begin{tabular}{|c|c|c|c|c|c|c|c|c|c|c|c|c|}
\hline $\begin{array}{c}\text { Cadila } \\
\text { Healthcare Ltd }\end{array}$ & 33.778 & 102.882 & 17.569 & 100.827 & 116.471 & 90.007 & 56.532 & 89.189 & 97.189 & 85.257 & 97.041 & 80.61 \\
\hline Divi'sLab Ltd & 70.8015 & 98.8584 & 85.4486 & 70.8653 & 106.818 & 74.835 & 61.185 & 78.968 & 70.498 & 97.094 & 93.203 & 82.59 \\
\hline Dr. Reddy's Ltd & 37.738 & 75.947 & 116.971 & 85.8085 & 148.115 & 27.568 & 153.77 & 22.821 & 46.849 & 106.353 & 206.585 & 93.5 \\
\hline Torrent Pharma Ltd & 79.4139 & 80.5381 & 148.6871 & 107.9119 & 147.984 & 80.21 & 127.688 & -12.75 & 40.674 & 170.923 & 134.261 & 100.52 \\
\hline $\begin{array}{c}\text { Aurobindo } \\
\text { Pharma Ltd }\end{array}$ & 5.4483 & 21.5994 & 36.2714 & 3.7965 & 65.5546 & 41.187 & -1182.9 & 125.995 & 27.987 & 38.936 & 118.719 & -63.4 \\
\hline Biocon Ltd & 30.257 & 75.9246 & 60.8664 & 103.757 & 91.9955 & 77.226 & 62.818 & 126.224 & 57.274 & 34.607 & 22.737 & 67.61 \\
\hline $\begin{array}{c}\text { Piramal } \\
\text { Enterprises Ltd }\end{array}$ & 92.363 & 90.4663 & 44.1754 & -33.408 & 127.2686 & -37.68 & -577.29 & 756.711 & 512.483 & -903.89 & -671.51 & -54.58 \\
\hline
\end{tabular}

\section{Interpretation:}

Earnings Quality is said to be good for a company if it is above $100 \%$ and the ratio remains stable over the period and there is no wild fluctuation in the value. The above Table-l Indicates that only Torrent Pharma Ltd. has highest average earning quality above $100 \%$ indicating consistency in financial performance but the performance is not promising. It is followed by dr. Reddy's ltd. has average $93.5 \%$ earnings quality ratio indicating that this company is making improvement in its financial performance. There is high volatility in the earnings quality of Aurobindo Pharma Ltd and Piramal Enterprises Ltd. There is a huge fluctuation in the quality of earnings among the selected companies. It indicates sheer inefficiency and lack of clarity on part of the management of these companies.

\section{- Discretionary Accruals (De-Āngelo Model):}

As Discretionary Accruals is a proxy to earnings management, their trend indicates income-accrual management exercised by a company. If the trend in accruals is negative (positive), it indicates managers are making income-decreasing (increasing) accrual decisions, for example more(less) depreciation or decrease(increase) in inventory. Discretionary Accruals have been computed using the De-Angelo Model.

Table No.: 2: Discretionary Accruals

\begin{tabular}{|c|c|c|c|c|c|c|c|c|c|c|}
\hline Years & $\begin{array}{c}\text { Cipla } \\
\text { Ltd }\end{array}$ & $\begin{array}{c}\text { Lupin } \\
\text { Ltd }\end{array}$ & $\begin{array}{c}\text { Sun } \\
\text { Pharma Ltd }\end{array}$ & $\begin{array}{c}\text { Cadila } \\
\text { Healthcare Ltd }\end{array}$ & $\begin{array}{c}\text { Divi's } \\
\text { Lab Ltd }\end{array}$ & $\begin{array}{c}\text { Reddy's lab. Ltd } \\
\text { Reddarma Ltd }\end{array}$ & $\begin{array}{c}\text { Torrent } \\
\text { Pharma- } \\
\text { bindo Ltd }\end{array}$ & $\begin{array}{c}\text { Biocon } \\
\text { Ltd }\end{array}$ & $\begin{array}{c}\text { Piramal } \\
\text { Pharma Ltd }\end{array}$ \\
\hline 2006 & 0.0463 & 0.0836 & 0.02 & 0.0752 & -0.017 & 0.11 & -0.009 & 0.06 & 0.07 & 0.06 \\
\hline 2007 & 0.0008 & 0.0354 & 0.007 & -0.0747 & -0.028 & 0.04 & 0.01 & 0.05 & -0.05 & 0.003 \\
\hline 2008 & -0.0026 & 0.0186 & 0.051 & 0.106 & 0.0578 & -0.06 & -0.1 & 0.002 & 0.1 & 0.08 \\
\hline 2009 & 0.0143 & -0.061 & -0.071 & -0.0859 & 0.06 & 0.03 & 0.05 & -0.01 & -0.09 & 0.09 \\
\hline 2010 & -0.0546 & 0.0336 & 0.038 & -0.0313 & -0.093 & -0.07 & -0.05 & 0.01 & 0.01 & -0.18 \\
\hline 2011 & -0.0091 & 0.0537 & -0.012 & 0.0501 & 0.07 & 0.13 & 0.08 & 0.03 & 0.04 & 6.36 \\
\hline 2012 & -0.0585 & -0.0047 & 0.026 & 0.065 & 0.044 & -0.12 & -0.06 & -0.15 & -0.003 & -1.28 \\
\hline 2013 & 0.0719 & -0.0121 & 0.006 & -0.049 & -0.029 & 0.14 & 0.27 & 0.06 & -0.06 & 0.05 \\
\hline 2014 & -0.0478 & 0.0772 & -0.09 & -0.005 & 0.033 & 0.004 & -0.05 & 0.14 & 0.07 & 0.0003 \\
\hline 2015 & 0.0428 & -0.142 & -0.086 & 0.026 & -0.055 & -0.07 & -0.21 & 0.009 & 0.03 & 0.13 \\
\hline 2016 & -0.0302 & 0.217 & 0.048 & -0.018 & 0.011 & -0.08 & -0.02 & -0.12 & 0.12 & 0.27 \\
\hline Average & -0.0024 & 0.0272 & -0.0057 & 0.0053 & 0.0049 & 0.0049 & -0.0081 & 0.0074 & 0.0215 & 0.5075 \\
\hline
\end{tabular}

Interpretation:

- The table-2 indicates the discretionary accrual practices exercised by the selected companies during the period under study.

- The earnings management trend predicts a positive discretionary accrual performance in pharmaceutical sector, on an average basis.

- The table-2 shows that compared to Piramal Enterprises Ltd, the other companies have low discretionary accruals. It is having large amount of fictitious assets as compared to other companies indicating high manipulation in financial statements.

Table No.: -3 Manipulation Score of Sample Companies

\begin{tabular}{|c|c|c|c|c|c|c|c|c|c|c|}
\hline Years & Cipla Ltd. & Lupin Ltd. & $\begin{array}{c}\text { Sun } \\
\text { Pharma Ltd }\end{array}$ & $\begin{array}{c}\text { Cadila } \\
\text { Health Care Ltd }\end{array}$ & $\begin{array}{c}\text { Divi's } \\
\text { lab }\end{array}$ & $\begin{array}{c}\text { Dr. } \\
\text { Reddy's lab }\end{array}$ & $\begin{array}{c}\text { Torrent } \\
\text { Pharma }\end{array}$ & $\begin{array}{c}\text { Auro } \\
\text { Bindo Pharma }\end{array}$ & $\begin{array}{c}\text { Biocon } \\
\text { Ltd }\end{array}$ & $\begin{array}{c}\text { Piramal } \\
\text { Pharma }\end{array}$ \\
\hline 2006 & -1.844 & -2.387 & -4.840 & -1.687 & 18.089 & -2.1730 & -2.537 & -2.277 & -2.008 & -2.105 \\
\hline 2007 & -1.703 & -1.386 & -1.795 & -2.313 & -1.8157 & -1.784 & -0.843 & -2.379 & -1.852 & -2.195 \\
\hline 2008 & -1.541 & -1.156 & -2.577 & -1.775 & -1.5364 & -1.397 & -2.530 & -2.172 & -1.758 & -2.356 \\
\hline $\mathbf{2 0 0 9}$ & -1.786 & -2.375 & 0.720 & 24.889 & -1.6108 & -1.917 & -2.040 & -1.403 & -2.124 & -1.607 \\
\hline $\mathbf{2 0 1 0}$ & -2.291 & -1.608 & -2.609 & -3.047 & -2.3649 & -3.293 & -2.804 & -2.653 & -2.301 & -2.970 \\
\hline $\mathbf{2 0 1 1}$ & -2.837 & -2.779 & -2.106 & -2.282 & -1.1762 & -2.371 & -2.189 & -3.525 & -2.554 & 0.264 \\
\hline $\mathbf{2 0 1 2}$ & -2.175 & -2.325 & -2.813 & -2.998 & -1.9968 & -2.556 & -2.152 & -0.622 & -1.811 & -3.605 \\
\hline $\mathbf{2 0 1 3}$ & -2.452 & -1.871 & -1.424 & -2.369 & -2.3007 & -2.021 & -1.468 & -2.529 & -2.835 & -3.095 \\
\hline $\mathbf{2 0 1 4}$ & -2.215 & -1.3218 & -7.556 & -4.216 & -2.0137 & -1.596 & -1.477 & -1.705 & -2.476 & -3.126 \\
\hline $\mathbf{2 0 1 5}$ & -2.354 & -2.078 & -1.870 & -2.574 & -2.1189 & -2.311 & -1.702 & -2.164 & -2.64 & -12.99 \\
\hline $\mathbf{2 0 1 6}$ & -2.37 & -1.701 & -2.350 & -2.051 & -1.7171 & -2.800 & -2.793 & -2.553 & -2.551 & -4.069 \\
\hline Average & -2.1434 & -1.9080 & -2.656 & -0.0384 & -0.0511 & -2.202 & -2.049 & -2.180 & -2.265 & -3.441 \\
\hline
\end{tabular}

- Cipla Ltd, Sun Pharma Ltd and Torrent Pharma Ltd are exercising income-decreasing management and they are saving for the future. Thus, manipulation in the financial statements is high for Cipla Ltd, Sun Pharma Ltd, and Torrent Pharma Ltd while rest of the companies exercising income-increasing management and try to show overly picture of performance to their stakeholders.

- Manipulation Score (The Beneish M-Score Model): The manipulation score has been calculated using Beneish model with eight variables for the selected companies for the period of 2006-2016. 


\section{Interpretation:}

The table-3 shows the M-score of the selected companies. MScore greater than -2.22, signals a strong likelihood of a firm being a manipulator. The evidence indicates that the probability of manipulation increase with: (1) Unusual increases in receivables, (2) Deteriorating gross margins, (3) Sales growth, (4) Increasing accruals.

Average M-Score of Cipla Ltd, Lupin Ltd, Cadila Healthcare Ltd, Divis Lab and Torrent pharma clearly indicate high likelihood of firm being manipulator which is matter of concern for their stakeholders. Average M-Score of Dr.Reddy and Aurobindo is nearer to -2.22 so it is also under consideration on account of probable manipulation. Sun Pharma, Biocon and Piramal have lowest average manipulation score indicating that they are not involved in manipulation practices.

\section{Findings:}

The following are the major findings of the study:

- On the Earnings Quality parameter, only Torrent Pharma Ltd. has above $100 \%$ ratio. Aurobindo Pharma Ltd and Piramal Enterprises Ltd have negative Earning quality.

- From the analysis of discretionary accruals on the basis of DeAngelo model, it is found that the earnings management trend predicts a positive discretionary accrual performance in pharmaceutical sector, on an average basis. All of the selected companies are involved in earnings management practices either incomedecreasing or income-increasing manipulation practices.

- From Beneish M-Score model it is found that Cipla Ltd, Lupin Ltd, Cadila healthcare Ltd, Divi's laboratories Ltd, Dr. Reddy's laboratories Ltd, Torrent pharmaceuticals Ltd and AurobindoPharma Ltd are manipulators where as Sun Pharma Ltd, Biocon Ltd and Piramal Enterprises Ltd are not a manipulator during the period of study.

\section{CONCLUSION:}

- Discretionary accruals act as a proxy to earnings manipulation. This study examines accrual management in the selected pharmaceutical companies in India.

- Majority of the companies is having positive earnings quality indicating manipulation in their operating cash flow. Most of the units are found to be exercising incomeincreasing discretionary accruals, as verified by their positive average. Only Cipla Ltd, Sun Pharma Ltd and Torrent Pharma Ltd are exercising income-decreasing management on an average basis. So, manipulation in financial statement is high for these three companies. The lack of transparency inherent in financial reporting system implies that there is potential to misuse it as a powerful tool of earnings management by the management is high, especially where an organizational choice of discretionary accruals to earnings management exists.

- Beneish M-score model revealed that except Sun Pharma Ltd, Biocon Ltd and Piramal Enterprises Ltd, all other firms are manipulating financial statements.

\section{REFERENCES:}

1. American Accounting Association (1969) "Committee on External Reporting An Evaluation of External Reporting Practices", A Report of the 1966-68 Committee on External Reporting, The Accounting Review, Supplement:79123

2. Bistrova, J. \& Lace, N. (2012) "Quality of corporate governance system and quality of reported earnings: evidence from CEE Companies", Economics and Management, vol. 17, no. 1

3. Beneish, M.D. (2001) "Earnings Management: A Perspective", Managerial Finance, vol. 27, no. 12: 3-17

4. Li, Feng \& Abeysekera, Indra \& Abeysekera, F. (2011). Earnings management and the effect of earnings quality in relation to stress level and bankruptcy level of Chinese listed firms. Corporate Ownership and Control. Volume 9, Issue 1, 2011

5. Sandeep Goel (2012) "Demystifying Earnings Management through Accruals Management in India" Volume 37, No 1, January-March 2012.

6. Sandeep Goel (2013): "Decoding Gimmicks Of Financial Shenanigans in Telecom Sector in India", Accounting and Management Information Systems Vol. 12, No. 1, pp. 118-131, 2013
7. Normah Omar, RidzuanKunjiKoya, ZuraidahMohdSanusi, and NurAimaShafie(2014),"Financial Statement Fraud: A Case Examination Using Beneish Model and Ratio Analysis", International Journal of Trade, Economics and Finance, Vol. 5, No. 2, April 2014 